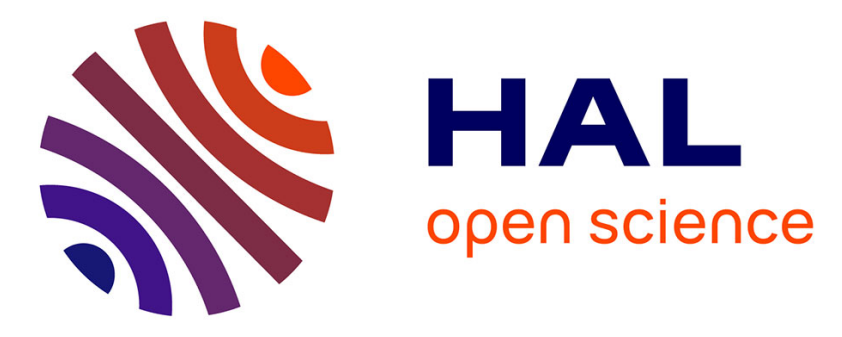

\title{
Paraneoplastic neuromyelitis optica and ovarian teratoma: A case series
}

\author{
Raphaël Bernard-Valnet, Alvaro Cobo-Calvo, Aurore Siegfried, Raluca \\ Marasescu, Mickael Bonnan, Guillaume Ballan, Emmanuel Ellie, Jan Bauer, \\ Emmanuelle Uro-Coste, Romain Marignier, et al.
}

\section{To cite this version:}

Raphaël Bernard-Valnet, Alvaro Cobo-Calvo, Aurore Siegfried, Raluca Marasescu, Mickael Bonnan, et al.. Paraneoplastic neuromyelitis optica and ovarian teratoma: A case series. Multiple Sclerosis and Related Disorders, 2019, 31, pp.97 - 100. 10.1016/j.msard.2019.03.031 . hal-03484440

\author{
HAL Id: hal-03484440 \\ https://hal.science/hal-03484440
}

Submitted on 20 Dec 2021

HAL is a multi-disciplinary open access archive for the deposit and dissemination of scientific research documents, whether they are published or not. The documents may come from teaching and research institutions in France or abroad, or from public or private research centers.
L'archive ouverte pluridisciplinaire HAL, est destinée au dépôt et à la diffusion de documents scientifiques de niveau recherche, publiés ou non, émanant des établissements d'enseignement et de recherche français ou étrangers, des laboratoires publics ou privés.

\section{(ㅇ)(1) $\$$}

Distributed under a Creative Commons Attribution - NonCommerciall 4.0 International 
Case report

\section{Paraneoplastic neuromyelitis optica and ovarian teratoma: a case series}

Raphaël Bernard-Valnet, PhD 1,2,3,*; Alvaro Cobo-Calvo ${ }^{4,5, *}, \mathrm{MD}, \mathrm{PhD}$; Aurore Siegfried ${ }^{6}$, MD; Raluca Marasescu, MD ${ }^{7}$; Mickael Bonnan, MD ${ }^{7}$; Guillaume Ballan, MD ${ }^{8}$; Emmanuel Ellie, MD ${ }^{8}$; Jan Bauer, $\mathrm{PhD}{ }^{9}$; Emmanuelle Uro-Coste, $\mathrm{MD}, \mathrm{PhD}^{6, *}$; Romain Marignier, $\mathrm{MD}, \mathrm{PhD}{ }^{4,5, *}$; David Brassat, $\mathrm{MD}, \mathrm{PhD}^{1,2, *}$

1. Center for pathophysiology Toulouse Purpan, INSERM U1043, CNRS 5282, Université Toulouse III, 31024 Toulouse, France

2. CRC-SEP, Pôle Neurosciences, CHU de Toulouse, 31059 Toulouse, France

3. Neurosciences and Medicine Departments, Centre hospitalier universitaire vaudois (CHUV), 1011 Lausanne, Switzerland

4. Service de neurologie, sclérose en plaques, pathologies de la myéline et neuro-inflammation and Centre de référence pour les maladies inflammatoires rares du cerveau et de la moelle (MIRCEM)- Hôpital Neurologique Pierre Wertheimer Hospices Civils de Lyon, Lyon, F6977, France.

5. Lyon's Neuroscience Research Center, U1028 INSERM, UMR5292 CNRS, FLUID Team F69008 Lyon, France

6. Service d'anatomo-pathologie, CHU de Toulouse, IUCT Oncopôle, Toulouse, France

7. Service de neurologie, CH Pau, 64000, Pau, France

8. Service de neurologie, $\mathrm{CH}$ de la Côte Basque, 64109, Bayonne, France

9. Center for Brain Research, Medical University of Vienna, Vienna, Austria

*. Contributed equally to this work

\section{Corresponding author:}

Dr. Raphaël Bernard-Valnet

Medicine Department, Centre hospitalier universitaire vaudois (CHUV)

CUTR Sylvana, Service de gériatrie et réadaptation gériatrique

Ch. de Sylvana 10, 1066 Epalinges, Suisse

raphael.bernard-valnet@chuv.ch

tel: +41795562169

\section{Number of words: 1145}

Number of tables/ figures: 1 table / 1 figure

Keywords: Demyelinating diseases, Neuromyelitis optica, Autoimmune diseases, Paraneoplastic syndromes, Ovarian teratoma 


\section{Abstract}

Neuromyelitis optica spectrum disorder (NMOSD) is a rare inflammatory disease of the central nervous system, characterized by the presence of auto-antibodies directed against aquaporin- 4 (AQP4) expressed on astrocyte end-feet. Despite NMOSD does not primarily belong to the spectrum of paraneoplastic neurological syndromes, rare cases of association with neoplasia have been outlined. Here, we report the association of NMOSD with ovarian teratoma in 3 cases. Pathological analysis of teratomas revealed glial component strongly expressing AQP4 and closely localized to immune infiltrates. Our series highlight the rare association of teratoma with NMOSD, and the possible paraneoplastic mechanism. 


\section{Introduction}

Neuromyelitis optica spectrum disorder (NMOSD) is a rare inflammatory disease of the central nervous system (CNS) mainly characterized by attacks of transverse myelitis and optic neuritis. Aquaporin-4 (AQP4) antibodies are currently the serological and pathophysiological marker of the disease, binding to the AQP4 water channel mostly expressed on astrocyte end-feet (Wingerchuk et al. 2007). Although the predilection for the optic nerve and spinal cord in NMOSD is widely known, the involvement of other CNS locations has led to the description of an expanding spectrum of clinical syndromes. Medullary floor of the fourth ventricule and area postrema are enriched with AQP4 conferring these structures a high susceptibility to be affected. Thus, the involvement of such structures located within the brainstem results in isolated intractable hiccups, nausea and/or vomiting, (referred as area postrema syndrome) inaugural in up to $10 \%$ of NMOSD cases (Shosha et al. 2018). Although a rarity, an underlying cancer may be present in a small proportion of AQP4-antibody-positive patients, mainly affecting older ages with brainstem involvement (Pittock and Lennon 2008; Sepulveda et al. 2018). However, association of NMOSD with teratoma, as observed inanti-NMDA receptor encephalitis, remains anecdotal(Frasquet et al. 2013). Herein, we report three NMOSD cases with ovarian teratoma who displayed area postrema symptoms at disease onset.

\section{Methods}

Three patients were identified from the NOMADMUS database (French collaborative network on NMO and related disorders) who fulfilled NMOSD criteria and presented an underlying ovarian teratoma. Clinico-radiological data were retrospectively collected at three different centers in France: Toulouse, Pau and Bayonne. Embedded teratomas were collected from local pathology services, and analyzed at Toulouse University Hospital by seasoned neuropathologists. All patients gave their written consent to be included into NOMADMUS study. AQP4-antibodies testing were performed by cell-based assay as previously described (Marignier et al. 2013), and 
glial fibrillar acidic protein (GFAP) antibodies testing according to Flanagan and colleagues' protocol(Flanagan et al. 2017).

\section{Results}

\section{Case 1}

Four months after teratoma ablation, a 15-year-old girl was admitted in internal medicine for a three weeks episode of intractable vomiting associated with severe asthenia, and weight loss. The patient was discharged after partial amelioration and no evidence of alterations in standard biological investigations. Two weeks later, the patient presented to the emergency room with a rapidly evolving tetraparesia and respiratory failure. She was admitted to intensive care unit requiringmechanical ventilation assistance. Brain and spinal cord magnetic resonance imaging (MRI) revealed two T2-weighted hyperintensities within the brainstem, and a cervical (C2, C4C5, C6-C7) myelitis (Fig 1A). At diagnosis, serum and cerebrospinal fluid (CSF) onconeuronal and anti-NMDA-R antibodies were negative. Serum AQP4-antibodies were tested positive. The patient recovered under intravenous (i.v) steroids, and rituximab was subsequently initiated. Evolution was excellent and currently she is asymptomatic after 2 years on rituximab.

\section{Case 2}

A 21-year-old girl was admitted in the gastroenterology Unit with nausea, vomiting, and headache associated with rapid loss of weight. Initial investigations including endoscopy and brain computed tomography (CT) scan showed no abnormalities. However, the patient progressively developed lower limb sensitive deficit, saddle anesthesia and urinary retention. Brain MRI revealed T2-white matter hyperintense lesions at multiple levels: hypothalamus, temporal lobes and area postrema. Spinal cord MRI displayed cervical (C3-C4), thoracic (T8) and conus T2-hyerintense lesions (Fig. 1B). Serum AQP4-antibodies were positive. The patient showed good recovery after plasma exchange, and i.v steroids. Two months later an abdominal 
and -pelvic CT scan revealed an ovary mass that proved to be a mature teratoma. Before removal, the patient developed two severe episodes of optic neuritis leading to important visual sequelae after 2 years. Nine months after onset of disease she was started on rituximab and experienced no further relapses.

\section{Case 3}

A 41-year-old woman was admitted to internal medicine department for asthenia within the previous month, bradycardia $(40 \mathrm{bpm})$, associated with loss of weight and rare vomiting episodes. The investigation revealed a right ovarian teratoma that was removed two weeks later. She regained a normal heart rate. Few weeks before the admission, the patient progressively developed sensory symptoms; suspended radicular sensory level (T10-L1), proprioceptive ataxia of the lower limbs, pyramidal irritation and mild saddle anesthesia symptoms. Anti-AQP4-and anti-GFAP-antibodies were found in CSF but not in serum. Other autoantibodies including onconeuronal and anti-NMDA-R-antibodies were negative in both serum and CSF. Spinal cord MRI displayed a short cervical (C1-C3) and longitudinally extensive transverse myelitis (from T3 to conus). Brain MRI was normal. She recovered after i.v. steroids, and mycophenolate mofetil was further introduced. The patient did not relapse after 2 years of

follow-up. Last neurological exam displayed only a mild sensory T10 level and last spinal cord MRI was normal. OCB persisted positive in CSF, but serum and CSF antibodies were again tested negative.

\section{Pathological findings}

All three teratomas revealed neuroglial tissue without immature component but including astrocytes revealed by a strong GFAP staining (Fig. 1D-F). This glial component highly expressed AQP4 but not myelin oligodendrocytes glycoprotein (MOG) (Fig. 1J and 1K). One histologic feature of these tumors was the presence of prominent lymphoid aggregates, mainly composed of CD20 B-cells which were localized close to the neuroglial tissue (Fig. 1D-1G). CD3 staining 
revealed a more spread $\mathrm{T}$ cell infiltrate predominantly composed of CD4 T lymphocytes. Only few CD8 T cells were present. No staining for C9neo, a marker of complement activation, was found.

\section{Discussion}

Here we report three AQP4-antibody-positive NMOSD patients with lesions within the brainstem and spinal cord, in the context of ovarian teratoma.

The association of NMOSD with teratoma, expressing a neuroglial component and AQP4, raises the question of a paraneoplastic mechanism. Despite NMOSD is not thought to belong to paraneoplastic neurological disorders (PND), several NMOSD cases have been reported in association with AQP4 expressing tumors, preferentially lung and breast cancer (Pittock and Lennon 2008; Sepulveda et al. 2018). Even if, area postrema syndrome is a frequent initial symptom of NMOSD, it seems overrepresented in paraneoplastic presentations (Sepulveda et al. 2018; Shosha et al. 2018; Frasquet et al. 2013).

Although teratoma may be present in up to $50 \%$ of patients with NMDA-R-antibody encephalitis, the association of such neoplasm in the setting of NMOSD is a rarity (Frasquet et al. 2013). From a pathological standpoint, in our series teratomas shared a histological pattern with antiNMDAR-associated tumors composed of prominent B-cell lymphoid aggregates close to neuroglial tissue. Marked intra-tumor lymphoid infiltrates is a characteristic of anti-NMDARassociated tumors in contrast to those tumors without an underlying paraneoplastic manifestation (Dabner et al. 2012). Furthermore, the progressive disappearance of AQP4antibodies (table 1) and the absence of new relapses after tumor removal (under treatment) may suggest a paraneoplastic mechanism. This favorable disease course arise the question for immunosuppressive treatment maintenance.

One of our patients concomitantly developed AQP4and GFAP-antibodies which is a frequently feature associated with teratoma in anti-GFAP encephalomyelitis. Despite this patient did not 
develop typical anti-GFAP encephalomyelitis, myelitis and area postrema syndrome have been related to anti-GFAP autoimmunity (Ciron et al. 2019; Flanagan et al. 2017).

To conclude, these three cases highlight that NMOSD may be rarely related to a paraneoplastic mechanism in the context of ovarian teratoma, sharing important histological and clinical features with other antibody-mediated paraneoplastic neurological syndromes. 
Figures

Table 1 - Clinical, biological and pathological characteristics of reported cases

*Onconeuronal antibodies: anti-HU, anti Yo, anti RI, anti CV2, anti-amphyphisines and anti-EMA, anti-Ma1, Ma2, SOX1, neuropile

Figure 1 - MRI and pathological findings of paraneoplastic NMO patients. (A) Transversal T2 spinal cord MRI of case 1 (A) and 3 (C), Transversal T2 FLAIR Brain MRI of case 2 (B). Case 2 teratoma pathology stained with HE (D,E) and for GFAP (F), CD20 (G), CD3 (H), CD8 (I), AQP4 (J), MOG (K) and C9neo (L). 


\section{References}

Ciron, J., F. Sourdrille, D. Biotti, T. Tchoumi, A. Ruiz, R. Bernard-Valnet, N. Maubeuge, and R. Marignier. 2019. 'Area postrema syndrome: Another feature of anti-GFAP encephalomyelitis', Mult Scler: 1352458518817992.

Dabner, M., W. G. McCluggage, C. Bundell, A. Carr, Y. Leung, R. Sharma, and C. J. Stewart. 2012. 'Ovarian teratoma associated with anti-N-methyl D-aspartate receptor encephalitis: a report of 5 cases documenting prominent intratumoral lymphoid infiltrates', Int J Gynecol Pathol, 31: 429-37.

Flanagan, E. P., S. R. Hinson, V. A. Lennon, B. Fang, A. J. Aksamit, P. P. Morris, E. Basal, J. A. Honorat, N. B. Alfugham, J. J. Linnoila, B. G. Weinshenker, S. J. Pittock, and A. McKeon. 2017. 'Glial fibrillary acidic protein immunoglobulin $\mathrm{G}$ as biomarker of autoimmune astrocytopathy: Analysis of 102 patients', Ann Neurol, 81: 298-309.

Frasquet, M., L. Bataller, E. Torres-Vega, M. Duran-Moreno, J. M. Garcia-Verdugo, T. Sevilla, S. Rivas, F. Perez-Miralles, M. Simo-Castello, and B. Casanova. 2013. 'Longitudinally extensive transverse myelitis with AQP4 antibodies revealing ovarian teratoma', J Neuroimmunol, 263: 145-7.

Marignier, R., R. Bernard-Valnet, P. Giraudon, N. Collongues, C. Papeix, H. Zephir, G. Cavillon, V. Rogemond, R. Casey, B. Frangoulis, J. De Seze, S. Vukusic, J. Honnorat, C. Confavreux, and Nomadmus Study Group. 2013. 'Aquaporin-4 antibodynegative neuromyelitis optica: distinct assay sensitivity-dependent entity', Neurology, 80: 2194-200.

Pittock, S. J., and V. A. Lennon. 2008. 'Aquaporin-4 autoantibodies in a paraneoplastic context', Arch Neurol, 65: 629-32.

Sepulveda, M., N. Sola-Valls, D. Escudero, B. Rojc, M. Baron, L. Hernandez-Echebarria, B. Gomez, J. Dalmau, A. Saiz, and F. Graus. 2018. 'Clinical profile of patients with paraneoplastic neuromyelitis optica spectrum disorder and aquaporin-4 antibodies', Mult Scler, 24: 1753-59.

Shosha, E., D. Dubey, J. Palace, I. Nakashima, A. Jacob, K. Fujihara, T. Takahashi, D. Whittam, M. I. Leite, T. Misu, T. Yoshiki, S. Messina, L. Elsone, M. Majed, E. Flanagan, A. Gadoth, C. Huebert, J. Sagen, B. M. Greenberg, M. Levy, A. Banerjee, B. Weinshenker, and S. J. Pittock. 2018. 'Area postrema syndrome: Frequency, criteria, and severity in AQP4-IgG-positive NMOSD', Neurology, 91: e1642-e51.

Wingerchuk, D. M., V. A. Lennon, C. F. Lucchinetti, S. J. Pittock, and B. G. Weinshenker. 2007. 'The spectrum of neuromyelitis optica', Lancet Neurol, 6: 805-15. 


\section{D}

c

$$
\text { J }
$$
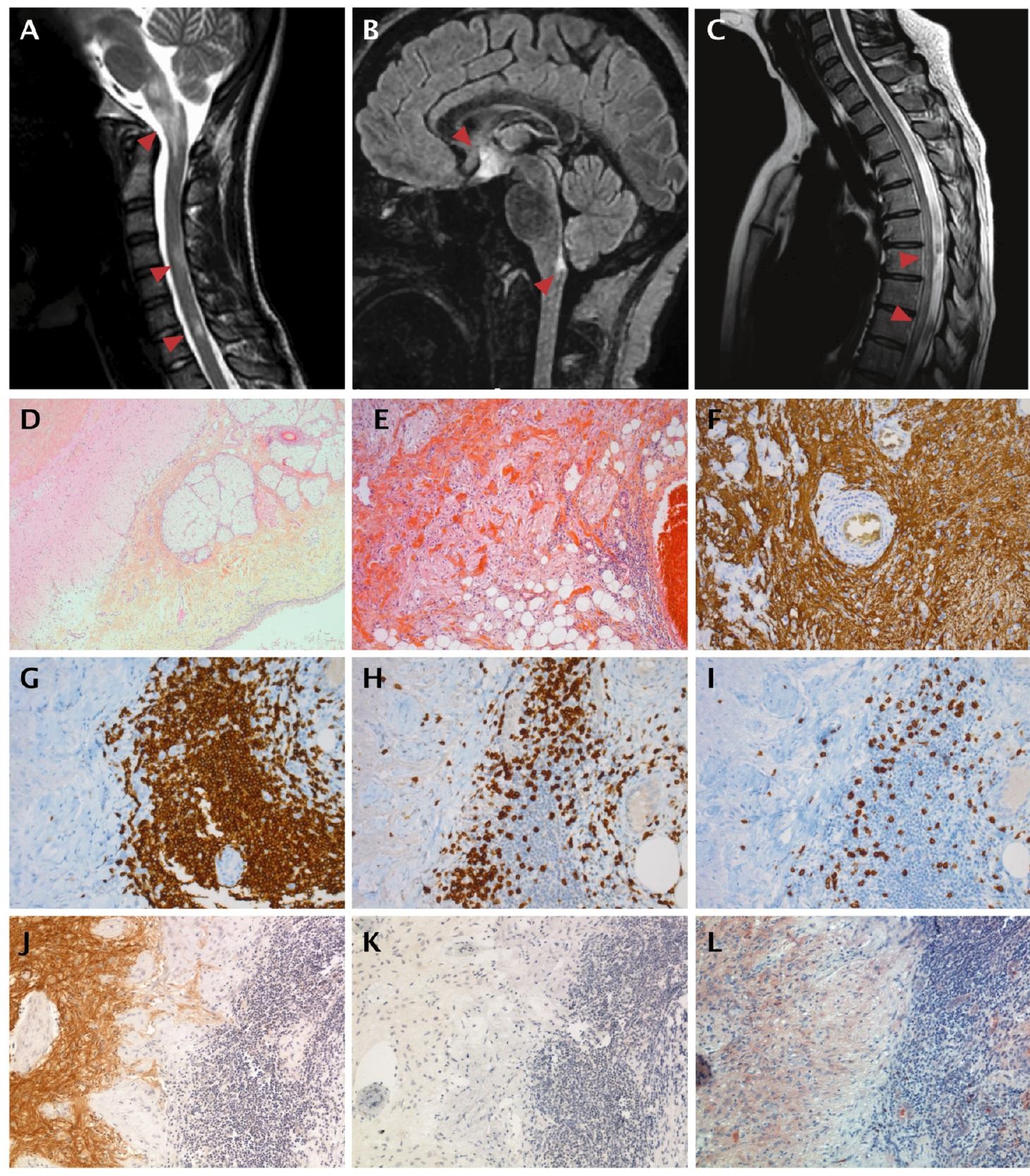

$K$
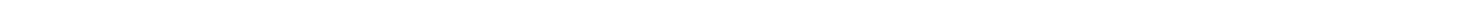

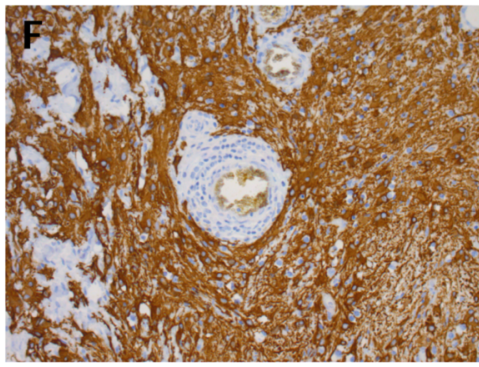

L

$\mathrm{N}^{2}+\mathrm{r}$
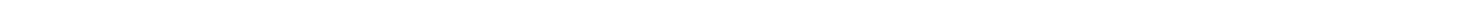


\begin{tabular}{|c|c|c|c|}
\hline & Case 1 & Case 2 & Case 3 \\
\hline Age, y / Sex & $15 / F$ & $21 / F$ & $41 / F$ \\
\hline Clinical presentation & $\begin{array}{l}\text { Nausea, Vomiting, } \\
\text { Asthenia, Tetraparesia, } \\
\text { Respiratory Failure }\end{array}$ & $\begin{array}{c}\text { Nausea, Vomiting, Lower } \\
\text { limbs sensory signs, Saddle } \\
\text { anesthesia, Urinary } \\
\text { retention }\end{array}$ & $\begin{array}{l}\text { Nausea, vomiting, ataxia, } \\
\text { lower limbs sensory signs }\end{array}$ \\
\hline Symptoms onset & $\begin{array}{c}4 \text { months after teratoma } \\
\text { ablation }\end{array}$ & $\begin{array}{c}1 \text { month before teratoma } \\
\text { discovery }\end{array}$ & $\begin{array}{c}3 \text { months before teratoma } \\
\text { discovery }\end{array}$ \\
\hline \multicolumn{4}{|l|}{ Auto-antibodies } \\
\hline - Anti-AQP4 & Pos & Pos & Serum Neg/ CSF Pos \\
\hline - Anti-NMDA-R & Neg & $\mathrm{Neg}$ & Neg \\
\hline - Anti-MOG & Neg & Neg & Neg \\
\hline - Anti-GFAP & Neg & $\mathrm{Neg}$ & Serum Neg/ CSF Pos \\
\hline - Onconeuronal* & $\mathrm{Neg}$ & $\mathrm{Neg}$ & Neg \\
\hline \multicolumn{4}{|l|}{ CSF } \\
\hline - Oligoclonal Bands & Pos & Pos & Pos \\
\hline - Pleiocytosis $\left(/ \mathrm{mm}^{3}\right)$ & 65 & 87 & 130 \\
\hline - Dominant population & Lymphocytes & Lymphocytes & Lymphocytes \\
\hline Treatment at the first episode & IV steroids (5g) & $\begin{array}{l}\text { IV steroids }(5 \mathrm{~g}) \\
\text { Plasma exchange }\end{array}$ & IV steroids (3g) \\
\hline \multicolumn{4}{|l|}{ Teratoma pathology } \\
\hline - Glial component & Yes & Yes & Yes \\
\hline - $\quad$ AQP4+ & Yes & Yes & Yes \\
\hline - Lymphoid structures & Yes & Yes & Yes \\
\hline \multicolumn{4}{|l|}{ Evolution } \\
\hline $\begin{array}{l}\text { - Treatment } \\
\text { - Clinic }\end{array}$ & $\begin{array}{c}\text { Rituximab, Tocilizumab } \\
\text { No relapse }\end{array}$ & $\begin{array}{c}\text { Rituximab } \\
2 \text { optic neuritis episodes } \\
\text { before teratoma ablation } \\
\text { No relapse }\end{array}$ & $\begin{array}{l}\text { Mycophenolate mofetil } \\
\text { No relapse }\end{array}$ \\
\hline \multicolumn{4}{|l|}{ Follow-up } \\
\hline - Anti-AQP4 & Neg & Neg & Neg (CSF) \\
\hline
\end{tabular}

